Studia Kinanthropologica, XX, 2019, (1), 105-115

The Scientific Journal for Kinanthropology

POROVNANIE AGRESIVITY A VYBRANYCH OSOBNOSTNÝCH CHARAKTERISTÍK U ŠPORTUJÚCEJ A NEŠPORTUJÚCEJ MLÁDEŽE

\title{
AGGRESSION AND SELECTED PERSONAL CHARACTERISTICS IN THE YOUTH ENGAGED/NOT ENGAGED IN SPORTS - COMPARA- TIVE STUDY
}

\author{
M. Rošková, \& A. Stehlíková \\ Univerzita Mateja Bela Banská Bystrica, Filozofická fakulta, Katedra telesnej výchovy a športu
}

\begin{abstract}
The paper aims to contribute to our understaning of aggression occurring in sports environment by identifying its manifestation factors among the youth engaged in sports. The research was a part of the VEGA 1/0760/16 project and it was aimed at gathering relevant data regarding the manifestations of aggression within the sports environment. To estimate aggression level, B -D-I test (Buss-Durkee Inventory) was employed, while the Eysenck Personality Questionnaire (EPQ) was used to identify personality types. Due to the complexity of the topic, we decided to investigate and compare data from individual levels of subtests gathered for young individuals doing sports and a "control sample" represented by normal population; we also investigated levels of overall aggression and hostility. All types of aggression were recorded much more frequently among the non-active youth group rather than in sportsmen. However, statistically significant differences at a significance level of 0.05 were detected only in irritability, resentment and overall hostility. As regards personality characteristics, higher level of extrovert behaviour and stability were recorded among the sportsmen rather than non-active group. Similarly, sanguine personality type prevailed among the youth engaged in sports, while choleric type dominated among those who did not do any sports.
\end{abstract}

Keywords: aggression; aggression; sports; youth; personality types

\section{Súhrn}

Cielom nášho príspevku je rozšririt poznatky týkajúce sa agresivity v športovom prostredí na základe identifikácie faktorov jej prejavov u športovcov. Zameranie nášho príspevku ktorý je súčastou výskumného projektu VEGA 1/0760/16, je získat relevantné informácie o súvislostiach prejavov agresivity vzhladom na športové prostredie. Ako diagnostický nástroj pre zistovanie úrovne agresivity sme si zvolil B-D-I test (Buss-Durkee Inventory) a na identifikáciu osobnostných typov Eysenckov dotazník. Vzhladom na zložitost vztahov medzi agresivitou a športovou aktivitou sme pristúpili k zistovaniu a porovnávaniu úrovni jednotlivých subtestov medzi skupinou športovcov a kontrolnou skupinou bežnej populácie., ako aj úrovňou celkovej agresivity a celkovej hostility. Z výsledkov nášho šetrenia vyplýva, že u skupiny nešportujúcej mládeže sme vo všetkých druhoch agresivity zaznamenali vyššie vážené skóre ako u športovcov. Ale štatisticky významný rozdiel na $5 \%$ hladine sme zaznamenali len v irritabilite, resentimente a v celkovej hostilite. Pri zistovaní vybraných osobnostných čŕt, sme v našom súbore zaznamenali vyššiu mieru extroverzie a stability u športujúcej mládeže ako u nešportovcov, čo sa potvrdilo v skupine športovcov prevládajúcim osobnostným typom sangvinik a nešportujúcej mládeže dominoval osobnostný typ cholerik.

Klúčové slová: agresivita; agresia; šport; mládež; osobnostné typy

\section{Úvod}

Agresia tvorí základnú hnaciu silu, ktorú sa však musíme učit regulovat a usmerňovat. Je dôležité, v akých situáciách sa agresia vyskytuje, či je opodstatnená. V iných prípadoch môže pôsobit až 
deštruktívne. Prejavy agresie môžu byt rôzne, v závislosti od okolnosti (Smiková \& Kopányová, 2013). Agresia je útočenie, napadnutie, agresívne je také správanie, pre ktoré je charakteristické násilie, útočnost', deštrukcia, zámerné ubližovanie a poškodzovanie. Je to fyzická, verbálna alebo hanlivá útočnost', často sprevádzaná deštrukčnými činmi výpadmi. Agresia je správanie zamerané na poškodenie druhého človeka (Boroš, 2001). Riešenie konfliktov, ale aj rôzne náročné životné situácie môžu u človeka viest’ k agresii a agresívnemu správaniu. V súčasnosti sa sústred’uje velká pozornost' na agresívne správanie detí a mládeže. Rôzne prejavy agresivity môžeme sledovat̉ už u detí na základných a stredných školách. Gajdošová (2001) zarad’uje medzi hlavné faktory ovplyvňujúce vznik agresie faktory biologické, spoločenské, školské a najmä faktor rodiny, v ktorej dieta vyrastá.

Výskumy agresívneho správania vo vztahu k prostrediu ukázali, že l’udia sa častejšie stávajú agresívnymi, ak je agresívne správanie nejakým spôsobom posilňované. Mnohí psychológovia sa snažili nájst’ odpoved, vysvetlit’, prečo sa l’udia správajú agresívne. Teórie poukazujú na dôležité aspekty a stránky agresie, no nad’alej nie je jednoznačné, nakol'ko je agresia vrodená a do akej miery môže byt̉ získaná. Teórie agresie, môžeme rozdelit na inštinktivistické, psychoanalytické, vysvetlujúce agresiu ako naučené správanie a tie, ktoré k vzniku agresie pristupujú komplexne.

$\mathrm{Na}$ vzniku agresívneho správania sa bezpochyby podielajú genetické vplyvy, ale predovšetkým sa zdôrazňuje význam ich interakcie s prostredím a z tohto pohladu ešte len kombinácia špecifického temperamentu a prostredia podporujúceho agresivitu vedie k vzniku agresívneho správania (Myers, 2010). Najdôležitejším východiskom poznania osobnosti športovca je podla Slepičku, P., Hošeka, V. \& Hátlovej, B. (2009) vývojový prístup. Spočíva v rešpektovaní faktu, že osobnoste športovca je určovaná dlhodobým pôsobením troch skupín činitelov:

1. vrodené anatomicko-fyziologické predpoklady športovcov;

2. životné prostredie predšportové, športové a mimošportové;

3. společenskovýchovné pôsobenie (sociálne učenie):

- nesystematické individuálne učenie napodobňovaním;

- inštitucionálna systematická výchova a rozvoj výkonnosti.

Šport je úzko spätý s agresivitou. Táto agresivita je ponímaná skôr ako asertivita, teda schopnost? presadit sa. Často práve táto schopnost’ prispieva k žiadanému výsledku uspiet a preto je vyžadovaná trénermi, rodičmi, divákmi. Agresívne správanie je však v každom športe limitované pravidlami pre daný šport. Tieto pravidlá určujú čo je dovolené a čo nie. Za porušenie pravidiel existujú špecifické postihy pre športovcov. Velakrát je však okolím športovca vytváraný tlak na porušovanie stanovených pravidiel v záujem dosiahnutia úspechu. Je ale šport fenomén, ktorý agresivitu mladých l’udí zvyšuje?

Väčšina agresií v športe je emocionálnych, majú vyprovokovaný charakter, napr. odveta, ale časté sú aj agresie taktické, bez hnevu a zlosti, kde je poškodenie protivníka v rámci pravidiel plánovaným prostriedkom k dosiahnutiu športového vítazstva. Dané agresie sa v športe málokedy vyskytujú v čistej podobe, nakolkko mnoho emócií v agresívnom správaní športovca môže viest' k nezvládnutel’nému afektu s konfliktným koncom a agresia bez emócií nie je pravou športovou bojovnostou (Gregor, 2013).

V športe je jedinec postavený, podobne ako v živote, do situácií, ktoré od neho vyžadujú agresívne správanie v rôznych formách. Z daného hladiska je teda agresivita chápaná ako neodlučitelná súčast? športového boja, ktorá má svoje opodstatnenie pri vyrovnávaní sa s prekážkami v športovom zápolení. Bez agresivity a útočnosti je športový boj tažko predstavitelný. Sú ale potom športovci agresívnejší ako bežná populácia aj mimo športového zápolenia?

Podla Jarvisa (2006) doterajšie výskumy nepotvrdili vplyv športu na zvyšovanie agresivity u športovcov v porovnaní s bežnou populáciou. Sližik (2006) vo svojom výskume konštatuje, že športová činnost konkrétne tréning $\mathrm{v}$ karate pôsobí u detí nie len $\mathrm{v}$ procese priameho potláčania agresivity, ale aj pri jej prevencii. Gregor (1999) vykonal porovnanie agresivity v osobnosti futbalistov a nešportovcov vo veku 18 rokov. Hypotéza, že futbalisti budú agresívnejší ako nešportovci sa nepotvrdila. Pačesová \& Putala (2017) skúmali úroveň agresivity plavcov, úpolových športovcov a nešportovcov v adolescentnom veku. Pri svojom výskume použili dotazník BPAQ (Buss \& Perry, 1992) ktorý meria štyri položky a to fyzickú agresiu, verbálnu agresiu, hnev a hostilitu. Výskumom zistili, že najvyššia miera celkovej agresivity a verbálnej agresivity bola zistená u nešportovcov. Lemieux, Mckelvie \& Stout (2002) vykonali porovnanie agresivity u 86 športovcov a 86 nešportovcov na univerzitách. Ná- 
strojom na zistovanie agresivity bol dotazník agresivity BPAQ vytvorený Bussom \& Perrym (1992). Výskum nepotvrdil zvýšenú mieru agresivity v skupine športovcov.

Cielom predloženého príspevku je komparácia jednotlivých subtestov B-D-I, celkovej agresivity a celkovej hostility v skupine športujúcej a nešportujúcej mládeže, ako aj na základe identifikácie osobnostných dimenzií zistit temperamentové zastúpenie v sledovaných skupinách. Zameranie nášho príspevku ktorý je súčastou výskumného projektu VEGA 1/0760/16 „Vzṫah agresivity a vybraných osobnostných charakteristík športovcov v súvislosti k športovému zameraniu, výkonnosti a veku” je získat relevantné informácie o súvislostiach prejavov agresivity vzhladom na športové prostredie.

\section{Metodika}

Realizácia výskumu sa uskutočnila na stredných školách vo Zvolene a Banskej Bystrici, celkovú vzorku tvorilo po 50 žiakov v každej skupine. Skupinu športovcov tvorili chlapci ktorí hrávajú hokej, futbal, florbal a hokejbal a zúčastňujú sa tréningov minimálne trikrát týždenne a tiež absolvujú aj sútaže. Nešportovci boli chlapci ktorí nevykonávajú pravidelne žiadnu športovú činnost. Vek žiakov sa pohyboval od 15 do 19 rokov. V našom prípade sme na identifikáciu úrovne agresívneho správania použili štandardizovaný psychologický dotazník B-D-I, ktorý spadá pod štandardizované testy osobnosti. Autori vychádzali z predpokladu, že agresivita je komplexný fenomén a že je teda potrebné odlíšit niekolko podtried agresívneho správania. Vytvorili preto 8 tried, ktoré považujú za základné druhy agresivity: fyzická agresia, nepriama agresia, irritabilita, negativizmus, resentiment, podozrievavoste, verbálna agresia a pocit viny. Hodnoty váženého skóre v jednotlivých subtestoch, ktoré presiahli hodnotu 5, svedčia o nadmernom výskyte jednotlivých druhov agresie a sú teda nežiaduce. Celková agresivita je vyjadrená súčtom hodnôt subtestov $1+2+7$ a celková hostilitaje vyjadrená súčtom hodnôt subtestov $3+4+5+6$. Na identifikáciu osobnostných typov temperamentu sme použili Eysenckov dotazník (Gurský, 2008). Pri spracovávaní výsledkov výskumu sme v našej práci využili metódy deskriptívnej štatistiky a to aritmetický priemer, rozsah (minimum, maximum). Okrem metód deskriptívnej štatistiky sme využili aj metódy analytickej štatistiky, ktoré sme realizovali pomocou programov MS Excel 2010 a IBM SPSS Statistics 25. Normalitu rozloženia jednotlivých premenných (výsledkov subtestov B-D-I) v rámci skúmaných súborov sme zistovali pomocou Shapiro-Wilkovho testu pri $5 \%$ hladine významnosti. V prípade, ked’ bolo rozloženie premennej u oboch skúmaných súborov normálne sme na overenie hypotézy použili parametrický nepárový t-test. V prípade, ked’ rozloženie premennej v jednom alebo u oboch súborov nebolo normálne použili sme na overenie hypotézy neparametrický Mann-Whitneyho U test. V oboch použitých testoch bola hladina významnosti na úrovni $5 \%$.

\section{Výsledky a diskusia}

Fyzická agresia je popisovaná ako presadzovanie svojich práv použitím fyzického násilia voči iným osobám, zarad’ujeme sem bitky, facky nie však deštrukciu predmetov. Skupina športovcov sa ukázala ako menej agresívna v oblasti fyzickej agresie s priemernou hodnotou váženého skóre 3,32 bodu v porovnaní so skupinou nešportovcov, ktorých priemerná hodnota váženého skóre dosiahla 3,8 bodu (Graf 1.). Ani v jednej skupine sme nezaznamenali zvýšené hodnoty fyzickej agresie. P-hodnota pre obojstranný dvojvýberový t-test s rovnostou rozptylov je $0,41(0,41>0,05)$, čo znamená, že rozdiel v stredných hodnotách premennej Fyzická agresia medzi porovnávanými skupinami nie je štatisticky významný.

Priemerné hodnoty premennej u sledovanej skupiny športovcov a nešportovcov vykazujú štatisticky nevýznamný rozdiel. Predpokladáme, že tento výsledok mohol ovplyvnit fakt, že šport pôsobí pozitívne na celkovú osobnost’ mladého človeka, ktorý je disciplinovanejšś, môžeme predpokladat, že pravidelné trénovanie pravdepodobne znižuje vybitie agresivity nežiaducim smerom, no zároveň nabíja pozitívnou energiou. Športovec je naučený dodržiavat pravidlá a aj ked' v športe dochádza k fyzickým stretom, športovec si uvedomuje, že v prípade agresívneho správania a porušovania pravidiel bude sankcionovaný.

Nepriama agresia je položka ktorá predstavuje také spôsoby správania ako sú kanadské žartíky, náhle výlevy rozčúlenia, výbuch negatívneho afektu, ktorý nesmeruje na konkrétnu osobu, ide o podrazy, ked' sa nič nedarí. 
Graf 1./ Graph 1.

Hodnoty váženého skóre fyzickej agresivity $v$ teste B-D-I./ The values of the weighted score of physical aggression in Test B-D-I.

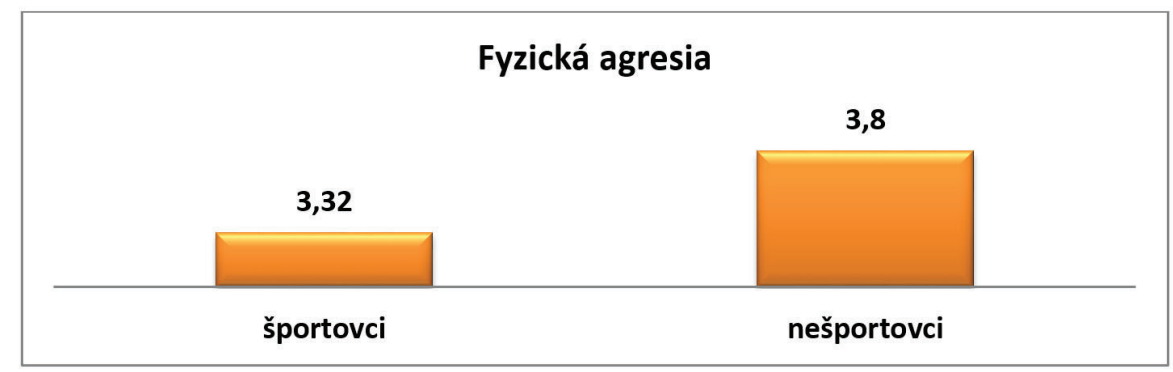

Vyššie hodnoty váženého skóre sme zaznamenali u nešportovcov $(5,19)$, čo sa považuje za mierne zvýšenú hodnotu nepriamej agresie. U športovcov je hladina bodového skóre 4,4 (Graf 2.), ktorá je pod hodnotou zvýšenej normy. T-test nám ale ukázal, že rozdiel v stredných hodnotách premennej Nepriama agresia medzi porovnávanými skupinami nie je štatisticky významný $(\mathrm{p}=0,21>0,05)$. Skupina športovcov sa nám ukázala ako menej agresívna v oblasti nepriamej agresie v porovnaní so skupinou nešportovcov. Predpokladáme, že tento rozdiel môže byt spôsobený tým, že športovec si uvedomuje, že je súčastou kolektívu, v ktorom zlá atmosféra spôsobuje zlý výkon, realizuje sa v športe a nemá čas, nerieši malichernosti, kým nešportovcov rozčulujú aj bežné maličkosti, sú viac hádaví, majú viac času na ohováranie, klebety či žartíky voči inej osobe.

Graf 2./ Graph 2.

Hodnoty váženého skóre nepriamej agresivity $v$ teste B-D-I./ The values of the weighted scores of the indirect aggression in Test B-D-I.

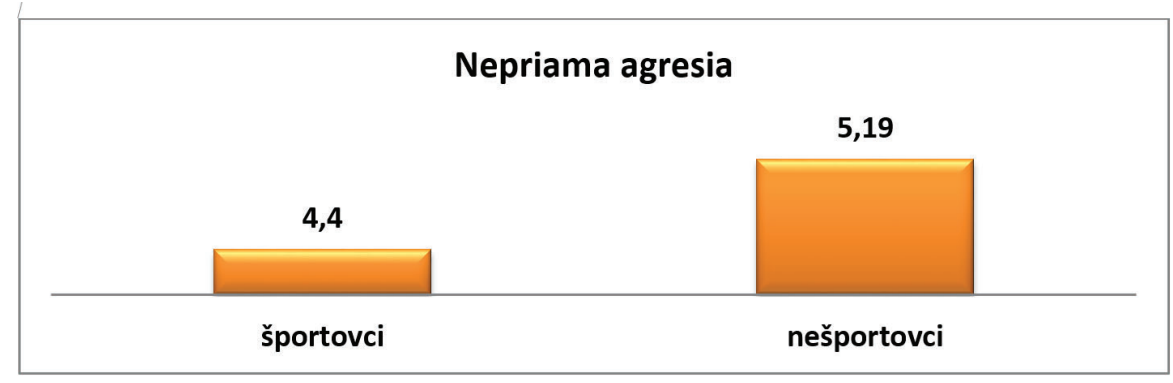

Irritabilita je popudlivost', neadekvátna reaktivita aj na malé podnety, podráždenost̉ človeka, frflošstvo.

V našom subteste B-D-I skupina nešportovcov dosiahla hodnotu 5,02 bodov váženého skóre, čím mierne prekročila hraničnú hodnotu váženého skóre 5bodov a v skupine športovcov sme zaznamenali hodnotu váženého skóre 3,24 bodu. Podla výsledku T-testu $\mathrm{p}=0,01<0,05$ je medzi porovnávanými skupinami štatisticky významný rozdiel. Výsledky naznačujú, že mládež ktorá sa venuje športovej činnosti má nejaký ciel', naplnenie svojho volného času a to pozitívne ovplyvňuje ich prejavy irritability. Predpokladáme, že žiaci športovci sú naučení kontrolovaț svoje emócie, hnev, zlost', popudlivoste, nemôžu si dovolit’ reagovat na provokácie, a tým, že sa pravidelne zúčastňujú tréningového procesu, sa zvyšuje ich trpezlivost. Zvýšená telesná aktivita športovcov produkuje v tele „hormóny šţastia” endorfíny, a tým sa znižuje ich podráždenost.

Negativizmus je charakterizovaný ako opozičné správanie voči autoritám, odmietanie spolupráce, až pasívna neochota a otvorený odpor voči pravidlám a zvyklostiam. V našom výskume sme nezaznamenali ani v jednej skupine zvýšené hodnoty váženého skóre, no zaznamenali sme vyššie hodnoty u nešportovcov $(4,48)$ ako u športujúcej mládeže $(3,68)$. Statistickú významnost̉ rozdielu výsledkov subtestu negativizmus sme overili pomocou dvojvýberového t-testu pre rovnost' rozptylov pri hladine 
významnosti $\alpha=0,05$. Podla výsledku testu $\mathrm{p}=0,25>0,05$ nie je medzi porovnávanými skupinami štatisticky významný rozdiel.

Graf 3./ Graph 3.

Hodnoty váženého skóre Irritability v teste B-D-I./ The values of the weighted scores irritability in Test B-D-I.

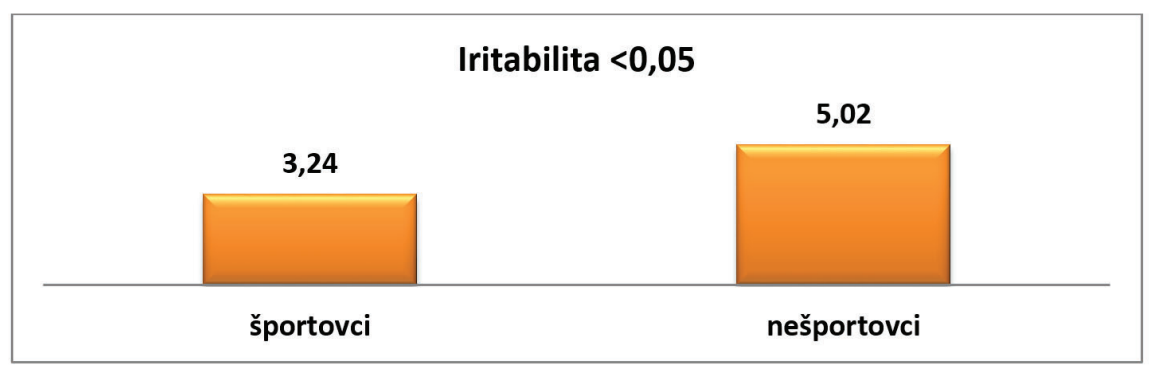

V našej výskumnej skupine športovcov sa nachádzajú chlapci, ktorí sú neustále pod dohladom trénerov, ktorých rešpektujú a rešpektujú aj dané pravidlá $v$ tíme. Tento rešpekt si prenášajú aj do bežného života $\mathrm{v}$ podobe rešpektu ku starším osobám a možno aj preto sa u nich vyskytli nižšie hodnoty váženého skóre negativizmu, ako u nešportovcov.

Graf 4./ Graph 4.

Hodnoty váženého skóre negativizmu v teste B-D-I./ The values of the weighted scores of negativity in Test B-D-I.

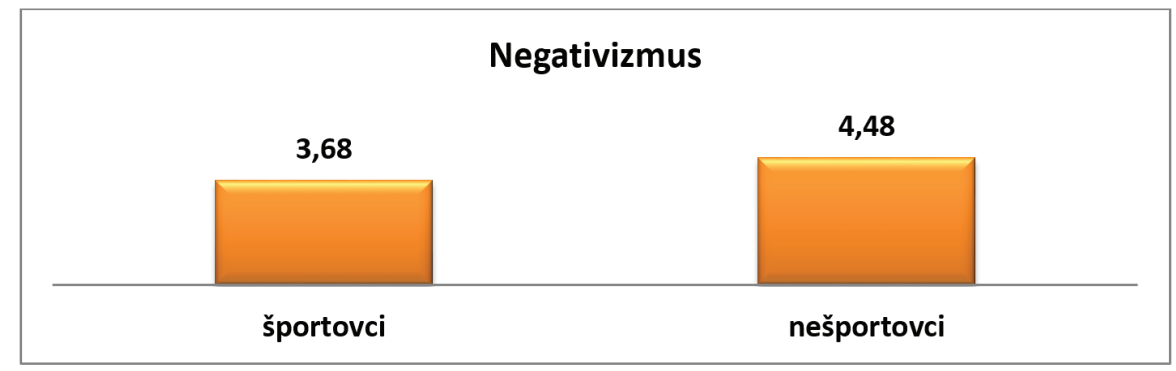

Graf 5./ Graph 5.

Hodnoty váženého skóre resentimentu v teste B-D-I./ The values of the weighted scores of resentment in Test B-D-I.

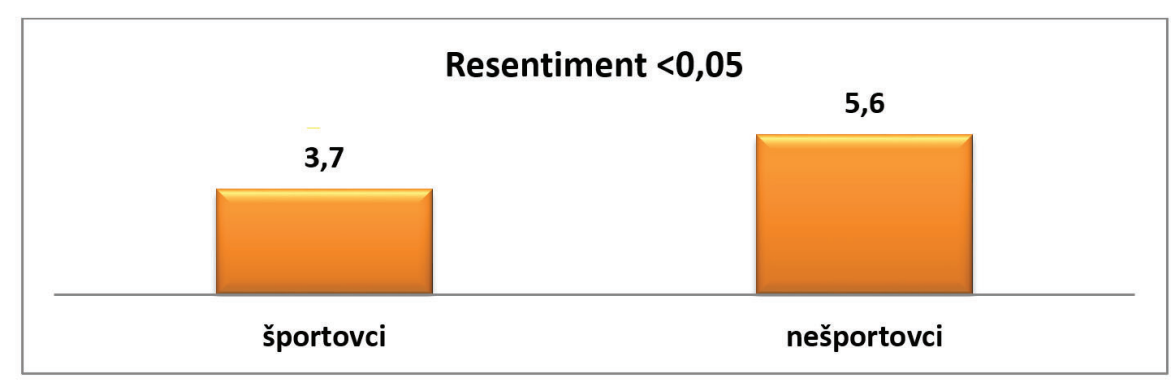

Položky Resentimentu vystihujú žiarlivoste, pocit zlosti na svet, pocit ubliženia svetom, zatrpknutost. V hodnotách váženého skóre sme v položke Resentiment (Graf 5.) zaznamenali u športovcov 3,7 bodu a u nešportovcov 5,6 bodu, čo je v prípade v skupine nešportujúcej mládeže zvýšená hladina tejto formy agresívneho správania. Štatistickú významnost̉ rozdielu výsledkov subtestu resentimentu sme overili pomocou dvojvýberového t-testu pre rovnost rozptylov pri hladine významnosti $\alpha=0,05$. 
Podla výsledku testu $\mathrm{p}=0,008<0,05$ je medzi porovnávanými skupinami štatisticky významný rozdiel. Tento rozdiel by sme mohli prisudzovat faktu, že športovci sa cítia zaujímavejší, atraktívnejší aj pre opačné pohlavie, necítia zatrpknutoste, v športe našli spôsob sebarealizácie.

Podozrievavost predstavuje projekciu hostility na druhých ludí, a to od nedôvery $\mathrm{k}$ l’ud’om až ostražitosti voči nim, s pocitom, že mi chcú ublížit. Aj v danej položke presiahla miera váženého skóre u nešportovcov hodnotu 5 bodov $(5,25)$, čo svedčí o zvýšenej podozrievavosti respondentov skupiny nešportovcov. V skupine športovcov sa bodová hranica váženého skóre $(4,92)$ nachádza tesne pod normou zvýšenej podozrievavosti. Podla výsledku testu $\mathrm{p}=0,63>0,05$ nie je medzi porovnávanými skupinami štatisticky významný rozdiel. Predpokladom nižšieho skóre v tejto dimenzii u športovcov môže zohrávat istú úlohu fakt, že v rámci kolektívnych športov je nutné si pre dosiahnutie dobrých výsledkov vytvorit si so spoluhráčmi a trénerom dobré vzţahy, dôvery a spolupatričnosti.

Graf 6./ Graph 6.

Hodnoty váženého skóre podozrievavosti $v$ teste B-D-I./ The values of the weighted scores suspiciousness in Test B-D-I.

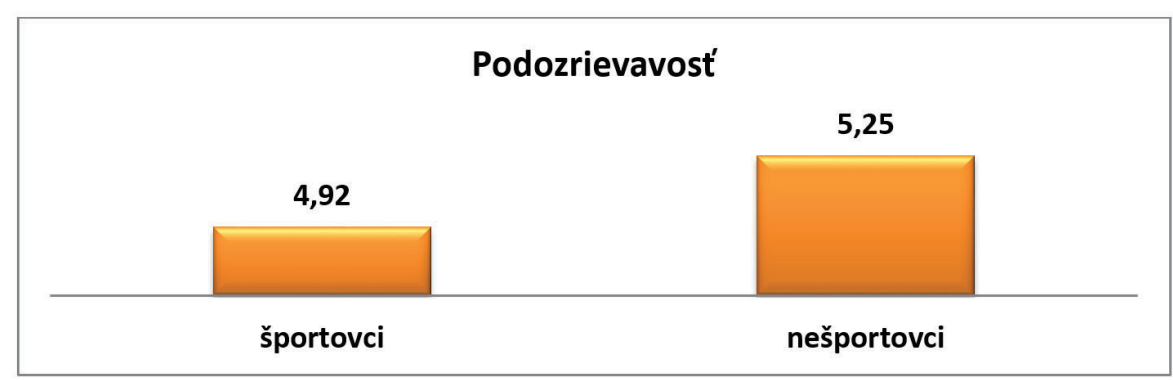

V danej položke Verbálnej agresie ide o negatívny afekt, pre ktorý je charakteristické hulákanie, hádanie sa, obsahom je prehnané kritizovanie, preklínanie, nadávanie či vyhrážanie. Zaujímavostou našich výsledkov je úplná zhoda priemernej hodnoty váženého skóre 5,88 (Graf 7.) a hlavne skutočnost', že vážené skóre verbálnej agresie nepresiahlo 6 bodov ani v jednej výskumnej skupine. V tejto položke je vážené skóre u našej populácie vyššie, ako je hraničná hodnota 5 bodov, uvádza sa až 7 bodov. Podla výsledku testu $\mathrm{p}=1,0>0,05$ nie je medzi porovnávanými skupinami štatisticky významný rozdiel. Gregor (2013) uvádza, že s prejavmi verbálnej agresie sa stretávame vo svete športu bežne, najčastejšie ide o zámerné znervózňovanie súpera pokrikovaním, kritizovaním rozhodcu, čo sa môže vystupňovat’ až ku priamym urážkam na cti. Ďalej ako uvádza Gajdošová (2013) agresivita študentov na školách je už skôr pravidlom ako výnimkou, študenti sa čoraz vulgárnejšie vyjadrujú bežne aj pred pedagógmi, a táto ústna agresivita často prerastá do fyzickej.

Graf 7./ Graph 7.

Hodnoty váženého skóre verbálnej agresivity v teste B-D-I./ The values of the weighted scores verbal aggressiveness Test B-D-I.

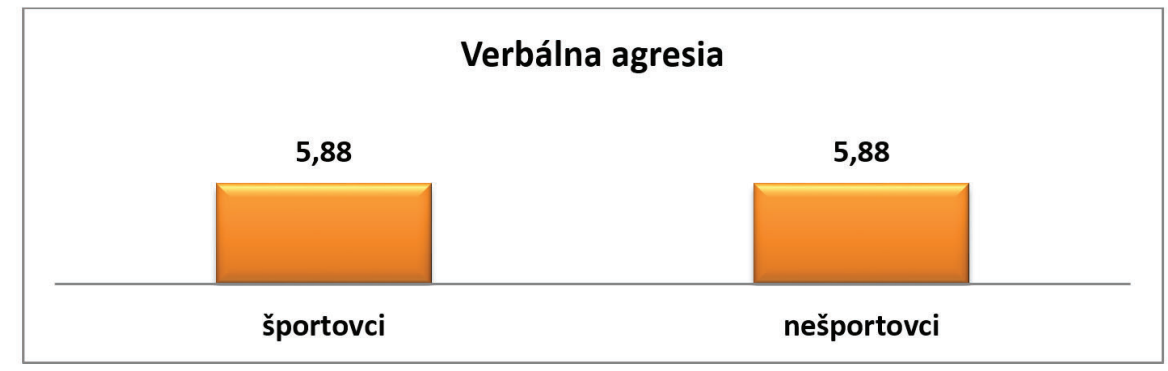

Posledná položka Pocit viny bola do testu B-D-I pridaná z vedeckých dôvodov, ide o pocit špatnosti $\mathrm{k}$ vlastnej osobe, kritickosti k sebe samému. Bodový priemer váženého skóre 5,16 u nešportovcov 
a presiahol hraničnú hodnotu 5 bodov, u športovcov sme zaznamenali hodnotu 4,62, ktorá nepresahuje zvýšenú hladinu tejto dimenzie. Podla výsledku testu $\mathrm{p}=0,41>0,05$ nie je medzi porovnávanými skupinami štatisticky významný rozdiel. Gregor (2013), uvádza že faktormi, ktoré ovplyvňujú pocit viny, sú etické zásady a sociálne normy človeka, ak človek vykoná niečo, čo je v rozpore s jeho presvedčením, môže trpiet pocitom viny, či je športovec, alebo nešportovec. V tomto prípade môžeme predpokladat, že okrem bežného života športovci musia v rámci športového zápolenie a pravidiel dodržiavat isté etické zásady a sociálne normy v rámci športového kolektívu a dodržiavania fair-play.

Graf 8./ Graph 8.

Hodnoty váženého skóre pocitu viny $v$ teste B-D-I./ The values of the weighted scores guilt in Test $B-D-I$.

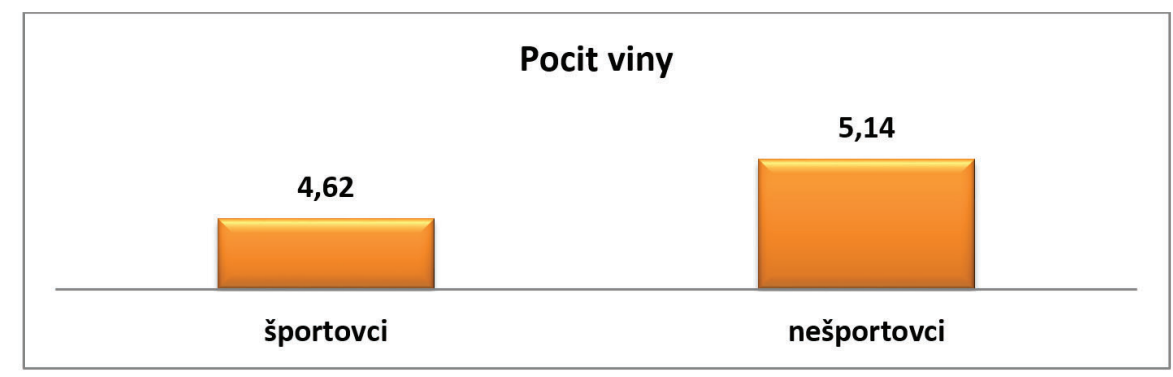

Hodnotu celkovej agresivity získame na základe vyhodnotenia položiek fyzickej, nepriamej a verbálnej agresivity a ich následným súčtom. V subteste celková agresivita je možné dosiahnut maximálne 30 bodov, pričom hodnoty presahujúce 15 bodov sú indikátorom zvýšenej agresivity. V našom prípade sme nezaznamenali ani v jednej skupine zvýšené hodnoty váženého skóre. U športovcov sme zaznamenali 13,6 bodov a u nešportovcov 14,87 bodov (Graf 9.). Podla výsledku testu $\mathrm{p}=0,46>0,05$ nie je medzi porovnávanými skupinami štatisticky významný rozdiel. Je pozitívnym zistením, že ani jedna naša výskumná skupina nepresiahla hodnotu 15 bodov, ktorá je indikátorom zvýšenej agresivity. Môžeme teda súhlasit, že biologická teória, postavená na tom, že pohyb tlmí agresívne prejavy, prispieva k znižovaniu napätia a tenzií, ktoré sa v jednotlivcovi hromadia.

Graf 9./ Graph 9.

Hodnoty váženého skóre celkovej agresivity v teste B-D-I./ The values weighted score of aggression in general in Test B-D-I.

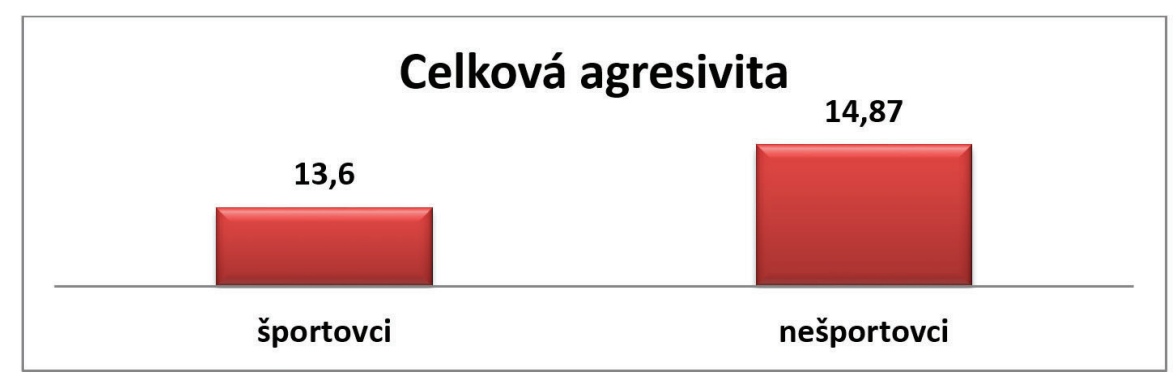

Hodnotu celkovej hostility získame na základe vyhodnotenia položiek irritability, resentimentu, negativismu a podozrievavosti a ich následným súčtom. V subteste hostilita je možné dosiahnut maximálne 40 bodov, pričom hodnoty presahujúce 20 bodov sú ukazovatelom zvýšenej hostility. Športovci dosiahli úroveň 15,54 bodov váženého skóre a skupina nešportovcov 20,34 bodov, čo je indikátorom zvýšenej celkovej hostility. Výsledky testu $\mathrm{p}=0,02<0,05$ preukázali, že medzi sledovanými súbormi je signifikantný rozdiel. Hostilita je prístupová - postojová reakcia ktorá trvá. Je obsiahnutá vo verbálnej reakcii a zahrňuje negatívne hodnotenie l’udí a udalostí. 
Graf 10./ Graph 10.

Hodnoty váženého skóre celkovej hostility $v$ teste B-D-I./ The values weighted score of hostility in general in Test B-D-I.

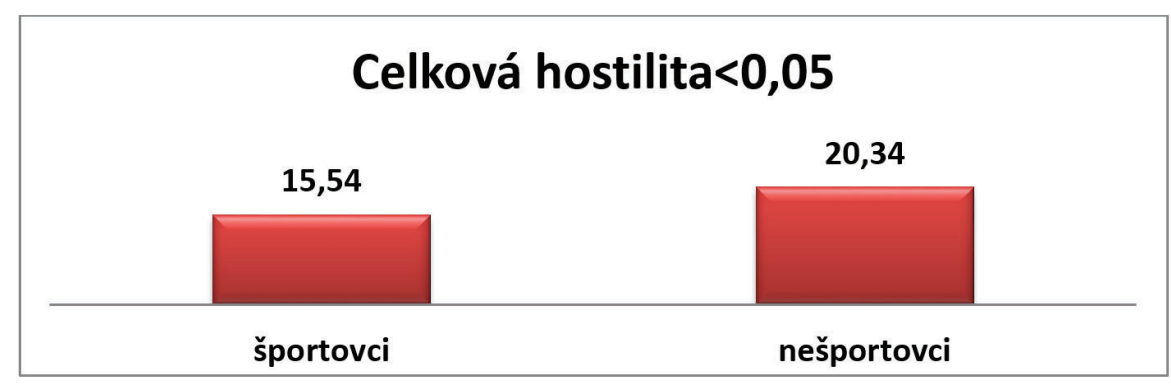

Podla Eysencka (1947) in Hall, C., Lindzey, G. (2002) je osobnost’ súhrnom aktuálnych lebo potencionálnych vzorcov správania organizmu, ktoré sú determinované dedičnostou a prostredím. Za základ extroverzie - introverzie pokladá dynamiku kôrových procesov vzrušivosti - excitácie a útlmu - inhibície. U extrovertov je kôrová dynamika excitácie a inhibície pohyblivejšia a vzrušivost̉ menšia. Extrovert vyžaduje zmenu a kontakty s l’ud’mi, ruch, má problémy v správaní (vyrušovanie, neposlušnost', hrubost'). Introvert je skôr typ stabilný s vyrovnaným priebehom neurofyziologických procesov a prevažujú u neho skôr osobnostné problémy (samotárstvo, roztržitost', náladovost, citlivost̉ a depresia). Osobnostná dimenzia extroverzia - introverzia sa týka vlastností osobnosti vztahujúcimi sa k sociálnemu prostrediu. Macák \& Hošek (1987) tvrdia, že návyky, ktoré si pestujú športovci od detstva, teda byt’ v kolektíve, spoločnosti, mat̉ kamarátov, byt̉ bezprostredný, dávajú vel'ký predpoklad na to, aby z nich boli väčšej miere extroverti ako introverti. Výsledky nášho zistenia poukazujú na vyššie percentuálne zastúpenie osobnostnej dimenzie extroverzie u športovcov $(77,44 \%$ ), ako u nešportujúcej mládeže sme zaznamenali 63,20 \%. Preukázali sme, že medzi sledovanými súbormi je štatisticky významný rozdiel $\mathrm{p}=0,0012<0,05$, čo nekorešponduje s výsledkami výskumu Zuzková, Stejskal, Malý \& Durkáč (2010), ktorí nezistili rozdiel medzi športovcami a bežnou populáciou.

Graf 11./ Graph 11.

Hodnoty extroverzie a introverzie u športovcov a nešportovcov./ Extrovert and introvert for those engaged in sports and a physically inactive youth.

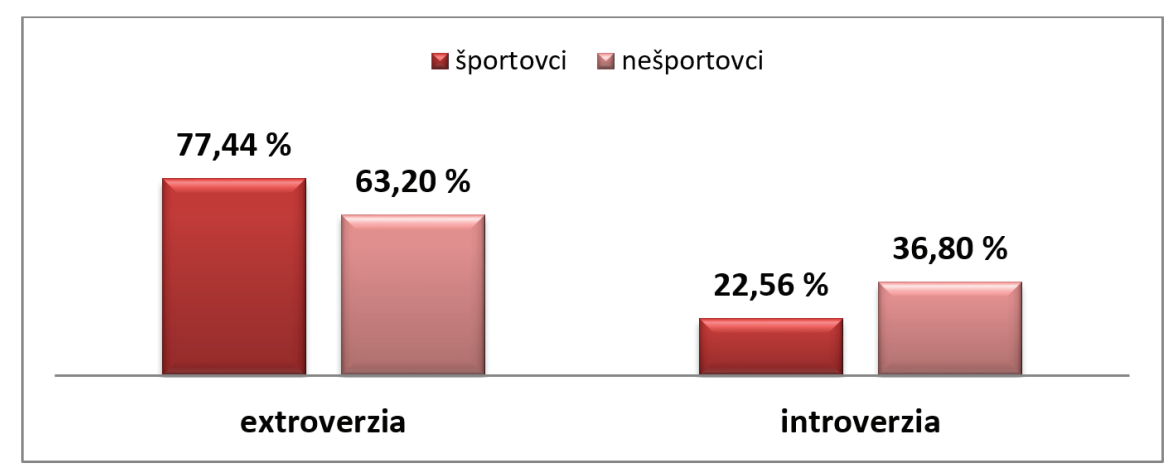

Neuroticizmus predstavuje určitú črtu osobnosti, ktorá na bipolárnom kontinuu neurostabilita - neurolabilita predstavuje také psychické vlastnosti, ktoré sú podmienené reaktivitou vegetatívnej nervovej sústavy prejavujúcou sa oko emocionalita športovca, disponovanost̉ k úzkostnosti, sila vôle rýchlost v myslení a správaní, senzorická citlivoste, úroveň aktivácie a podobne. Pri porovnaní miery neurostability a neurolability sme väčšie zastúpenie psychickej neurostability zaznamenali v skupine športovcov (61,44\%), ako u nešportovcov (39,84\%). Podl’a výskumov Potquiter \& Venter (1995) a Burgess (1997) zaoberajúcich sa úrovňou extroverzie a neuroticizmu u športujúcich osôb, došli 
k záveru že rozdiel v hodnotách extroverzie medzi športovcami a nešportovcami nebol signifikantný, ale u nešportujúcich sa prejavila vyššia miera neuroticizmu.

Graf 12./ Graph 12.

Hodnoty neurostability a neurolability u športovcov a nešportovcov./ Neurostability and neuroinstability for those engaged in sports and a physically inactive youth.

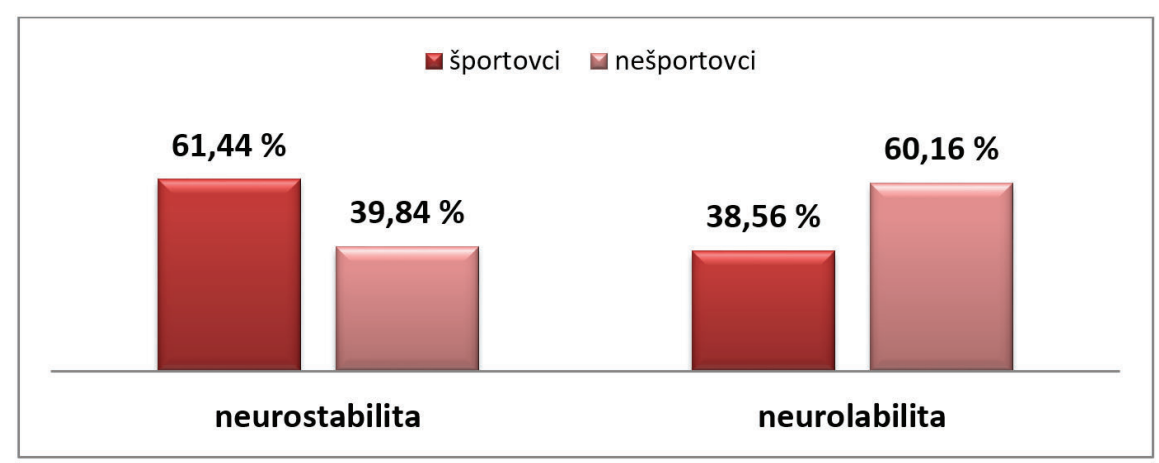

Graf 13./ Graph 13.

Zastúpenie osobnostného temperamentového typu u športovcov./ Personality types in young people doing sports.

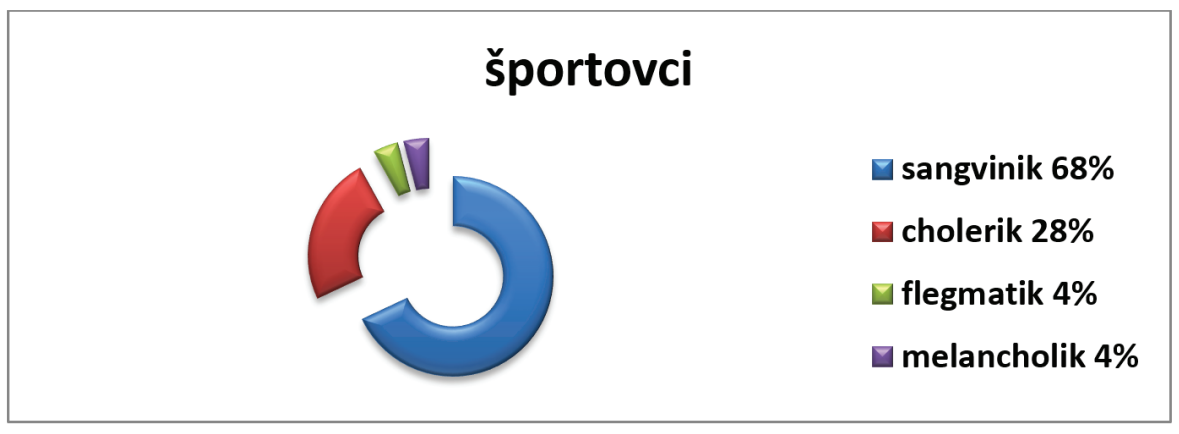

Graf 14./ Graph 14.

Zastúpenie osobnostného temperamentového typu u nešportovcov./ Personality types in a physically inactive youth.

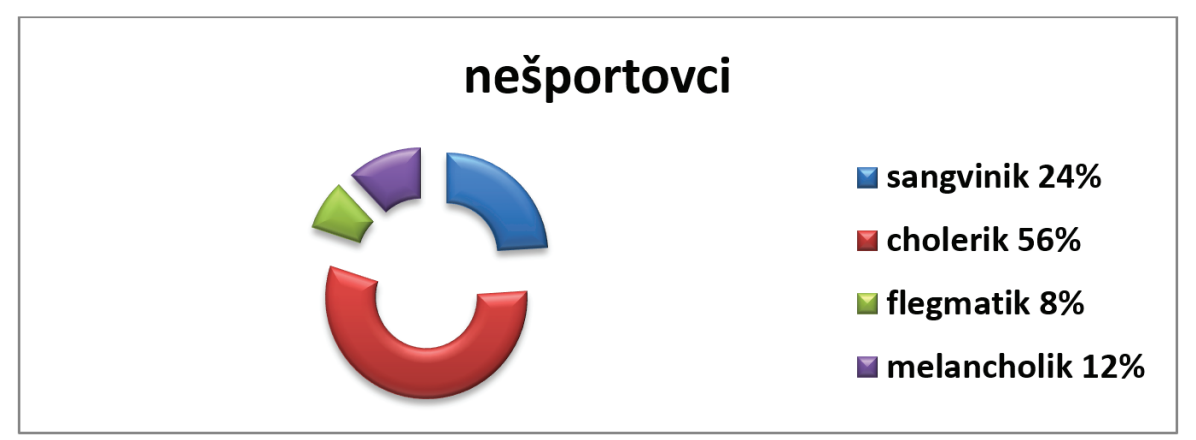

Zaznamenaním skóre neuroticizmu a extroverzie- introverzie do súradnicovéhosystému môžeme urobitodhad temperamenu osobnosti. Po pretnutí súradníc týchto dvoch škál na osy x - neuroticizmus a osy y - extroverzie - introverzie, získame umiestnenie športovca na určitom mieste $\mathrm{v}$ jednom zo štyroch kvadrantov cholerik, sangvinik, flegmatik a melancholik. Na základe našich výskumov sme zistili v skupine športovcov najvyšší výskyt 68 \% v kvadrante sangvinik a 28 \% v kvadrante cholerik. 
Podobné percentuálne zastúpenie temperamentu sangvinik (61,50\%) a cholerik (15,40\%) uvádza vo svojom výskume v skupine športovcov - karatisov aj Sližik \& Blahutková (2016).

V skupine nešportovcov prevládalo zastúpenie v kvadrante cholerik $56 \%$ a v kvadrante sangvinik sme zaznamenali $24 \%$. Môžeme konštatovat, že výsledky nášho výskumu korešpondujú s výsledkami výskumov Vaněk, Hošek, \& Svoboda (1974) a výskumom Zuzková et al., (2010). Gurský (2005) uvádza, že sangvinik má výrazné a navonok sa prejavujúce emócie, ktoré odzrkadlujú rýchlu adaptáciu na meniace sa vonkajšie podmienky a reakcie sú sprevádzané dostatočnou sebakontrolou. Na vysokú zátaž reaguje dobre, rýchlo sa adaptuje, je stabilný a priaznivý typ pre akúkolvek športovú činnost’. Novotná (2002) uvádza, že sangvinik má rýchlo striedajúce emócie so silnou intenzitou, ale je stabilný a má dobrú vnútornú sebakontrolu.

\section{Záver}

V skupine športovcov sme zaznamenali v takmer vo všetkých položkách testu B-D-I nižšie vážené skóre ako u nešportovcov. V subteste Verbálna agresia bola hodnota obidvoch skupín rovnaká. U nešportovcov sme zaznamenali zvýšenú hodnotu váženého skóre v subtestoch Nepriama agresia $(50,9)$, Irritabilita (5,02), Resentiment $(5,6)$, Podozrievavost' $(5,24)$, Pocit viny $(5,14)$ a tiež Verbálne agresia $(5,88)$ a u športovcov len v subteste Verbálna agresia $(5,88)$.

Aj v celkovej agresivite mali nešportovci vyššie skóre ako športovci, ale ani jedna skupina nepresiahla hodnotu 15 bodov, ktorá je indikátorom zvýšenej agresivity. Pri komparácii celkovej agresivity sme nezaznamenali medzi skupinami signifikantný rozdiel.

Zvýšenú hodnotu celkovej hostility 20,34 bodov sme zaznamenali u nešportovcov a rozdiel s priemerným váženým skóre športovcov 13,6 bodov bol signifikantný.

V našom výskumnom súbore sme zaznamenali vyššiu úroveň extroverzie u športujúcej mládeže oproti nešportovcom a vyššiu mieru neurolability u nešportujúcej mládeže. Kým u športovcov prevládal typ sangvinik (68 \%) a nasledoval cholerik (28\%), u nešportovcov prevládal typ cholerik $(56 \%)$ a potom sangvinik len $(24 \%)$.

Na základe zistení môžeme konštatovat, že v našom súbore vo väčšine subtestov B-D-I, ako aj v celkovej agresivite sme zaznamenali u nešportovcov vyššie hodnoty ako u športujúcej mládeže. V celkovej hostilite boli tieto rozdiely ešte markantnejšie, kde sme zaznamenali zvýšené hodnoty u nešportovcov a medzi športovcami a nešportovcami bol významný rozdiel. $\mathrm{K}$ podobným zisteniam ohladom agresívneho správania vo svojom výskume dospeli aj Sližik (2006) kde sa venuje mladým karatistom a Pačesová \& Putala (2017), ktorí porovnávali športovcov a nešportovcov.

Aj ked’ šport prináša vypäté situácie, vela emócií a snahu po vítazstve, učí športovcov v priebehu tréningov, ako aj v samotných sútažiach, sústredenosti, trpezlivosti, sebaovládania a spolupráce, čo sa následne môže prejavit aj na ich správaní a prejavoch agresivity, ako to ukazujú aj naše výsledky, že športovci vo väčšine subtestov agresivity dosiahli nižšie hodnoty oproti nešportovcom. Môžeme predpokladat že kooperácia s trénermi, ktorí na nich pôsobia aj po výchovnej a osobnostnej stránke, so spoluhráčmi, s ktorými tvoria jeden tím a celkovo športové prostredie, pôsobí pozitívne na športovcov a do určitej miery tlmí ich prejavy agresívneho správania. Samozrejme mali by sme brat̉ do úvahy aj druh športu a osobnost' trénera, ktorý so športovcami spolupracuje. V náväznosti s našimi predpokladmi možného kladného vplyvu športového prostredia na elimináciu agresivity, súhlasíme s autormi Slepička \& Slepičková (2012), ktorí cez teóriu sociálneho učenia, zdôrazňujúcu vplyv kultúry, noriem a hodnôt na prejavy nežiaduceho agresívneho správania a d’alej uvádzajú, že ak je športovec, ale aj obyčajný človek súčastou prostredia, ktoré kladie dôraz na vítazstvo za každú cenu, kde sú prejavy agresivity samozrejmostou, potom je agresívne správanie posilňované, a naopak, ak sa v prostredí kladie dôraz na sebakontrolu a fair play, pozitívne to vplýva aj na redukciu agresivity.

\section{Literatúra}

Boroš, J. (2001). Základy sociálnej psychológie. Bratislava: IRIS.

Burgess, S. (1977). Stimulus-seeking, Extroversion, Neuroticiscm in Regular, Occasional and NonExcercisers. Paper presented at the 1977 Annual Meeting of North American Society for the Psychology of Sport and Physica Activity.

Buss, A. H., \& Perry, M. (1992). The Aggression Questionnaire. Austin: University of Texax at Austin. Získané 29. decembra 2017, z http://citeseerx.ist.psu.edu/viewdoc/download?doi=10.1.1.455.5915 $\&$ rep $=$ rep $1 \&$ type $=$ pdf. 
Gajdošová, E. (2001). Problémy žiakov v správaní spojené s agresivitou a šikanovaním $v$ školách. Bratislava: MPC.

Gajdošová, E. (2013). Agresia a šikanovanie na školách. Bratislava: UK PF Katedra psychológie a patopsychológie.

Gregor, T. (1999). Porovnanie úrovne agresivity v osobnosti futbalistov a nešportovcov. In Telesná výchova a šport, 9(1), 51-54.

Gregor, T. (2013). Psychológia športu. Bratislava: Mauro.

Gurský, T. (2008). Test osobnosti. In Špeciálna psychodiagnostika pre športovcov a trénerov Bratislava: Získané 26. marca 2018, z http://www.top-fit.sk/testy/2-Test_osobnosti.xls.

Gurský, T. (2005). Psychlógia športu - čebné texty pre trénerov. Bratislava: SZTK.

Hall, C. \& Lindzey, G. (2002). Psychplógia osobnosti. Bratislava: SPN.

Jarvis, M. (2006). Sport Psychology: A Student's Handbook. New York: Routledge. Získané 29. decembra 2017, z http://memberfiles.freewebs.com/37/84/82578437/documents/1841695815.pdf.

Lemieux, P., Mckelvie, S. J., \& Stout, D. (2002). Self-reported Hostile Aggression in Contact Athletes, No Contact Athletes and Nonathletes. In Athletic Insight: The Online Journal of Sport Psychology, vol. 4, (3), Získané 29. decembra 2017, z https://www.researchgate.net/publication/255593015_Selfreported_Hostile_Aggression_in_Contact_Athletes_No_Contact_Athletes_and_Non_athletes.

Macák, I. \& Hošek, V. (1987). Psychológia telesnej výchovy a športu. Bratislava: SPN.

Myers, D. (2010). Social psychology. New York: McGraw-Hill.

Novotná, P. (2002). Sledování závislosti temperamentu a pohybové aktivity u mládeže (Diplomová práca, Brno).

Pačesová, P., \& Putala, M. (2017). Úroveň agresivity plavcov, úpolových športovcov a nešportovcov. Telesná výchova a šport, 27(1), 26-30.

Potquiter, J., \& Venter, R. (1995). Relationship between adherence to exerise and scores on extroversion and neuroticism. Perceptual and motor Skills, 81, 520-522.

Slepička, P., Hošek, V., \& Hátlová, B. (2009). Psychologie sportu. Praha: Karolinum.

Slepička, P., \& Slepičková, I. (2012). Kde hledat počátky moderního sportu. Geografické rozhledy, 4/11-12 str. Získané 13. mája. 2018, z http://www.ceskakinantropologie.cz/index.php/TestJournal/ article/viewFile/130/41.

Sližik, M. (2006). Vplyv bojového umenia karate na rozvoj niektorých osobnostných vlastnostídetí mladšieho školského veku. In: Násilie na školách. Zborník prác z 2. Ročníka medzinárodnej vedeckej konferencie Ďuričove dni (pp 271-281). Banská Bystrica: PF UMB.

Sližik, M., \& Blahutková, M. (2016). Struktúra osobnosti z hladiska temperamentu a emocionálna odolnost pretekárov v športovom karate. Studia Kinanthropologica, vol. 17, 443-450.

Smiková, E., \& Kopányová, A. (2013). Pedagogické možnosti znižovania agresivity detí v školskom veku. Bratislava: MPC.

Vaněk, M., Hošek, V., \& Svoboda, B. (1974). Studie osobnosti ve sportu. Praha: Universita Karlova.

Zusková, K., Stejskal, T., Malý, T., \& Durkáč, P. (2010). Osobnost’ športovca z pohl’adu vybraných oblastí psychológie a športu. Prešov: Prešovská univerzita.

Mgr. Miroslava Rošková, PhD.

FF KTVŠ UMB BB

Tajovského 40

97400 Banská Bystrica

Miroslava.roskova@umb.sk 